\title{
Evaluation of Different Drought Stress Regimens on Growth, Leaf Gas Exchange Properties, and Carboxylation Activity in Purple Passionflower Plants
}

\author{
Alexandra García-Castro \\ Department of Horticultural Sciences, Texas A\&M University, College Station, TX 77843 \\ Astrid Volder \\ Department of Plant Sciences, University of California, Davis, CA 95616 \\ Hermann Restrepo-Diaz \\ Departamento de Agronomía, Universidad Nacional de Colombia, Bogotá, Colombia \\ Terri W. Starman and Leonardo Lombardini ${ }^{1}$ \\ Department of Horticultural Sciences, Texas A\&M University, College Station, TX 77843
}

\begin{abstract}
Additional index words. $A / C$ i curves, leaf water potential, light response curves, water stress
Abstract. A greenhouse experiment was conducted to evaluate the effects of water stress on leaf water potential, plant growth, and photosynthesis in purple passionflower (Passiflora incarnata). Twenty 4-L pots with two plants in each pot were arranged in a completely randomized design. Ten pots received a daily irrigation dose of $100 \%$ evapotranspiration (ET) throughout the 43-day experiment (control). The other 10 pots were subjected to a reduced irrigation (RI) treatment, which was implemented stepwise to achieve a gradual increase in stress, by irrigating them with $50 \%$ ET first, then with $25 \%$ ET and, finally, with $10 \%$ ET. The last stress phase was followed by a recovery phase in which all treatments received the same amount of water $(100 \%$ ET). A lower water potential was obtained at $10 \%$ ET compared with control plants $(-2.51$ and $-0.98 \mathrm{MPa}$, respectively). Plants in both $25 \%$ and $10 \%$ ET irrigation treatments had reduced net $\mathrm{CO}_{2}$ assimilation rates $\left(4.25\right.$ and $3.50 \mu \mathrm{mol} \cdot \mathrm{m}^{-2} \cdot \mathrm{s}^{-1}$, respectively) than plants watered with $100 \% \mathrm{ET}\left(8.53\right.$ and $6.77 \mu \mathrm{mol} \cdot \mathrm{m}^{-2} \cdot \mathrm{s}^{-1}$, respectively). Values of maximum carboxylation rate allowed by rubisco (ribulose-1,5-bisphosphate carboxylase/oxygenase), calculated 31 days after treatment (DAT) application (when RI plants were irrigated with $10 \% \mathrm{ET}$ ) decreased by $\approx 60 \%$, whereas rate of photosynthetic electron transport and triose phosphate use (TPU) were reduced by $\approx 30 \%$ and $\approx 45 \%$ in the stress treatment compared with the control during the $10 \%$ ET irrigation period, respectively. Values of water potential and net $\mathrm{CO}_{2}$ assimilation rates in previously stressed plants were not different from the control treatment in the recovery phase, suggesting that $P$. incarnata plants could adapt well to landscaping situations where periods of extreme drought can be expected.
\end{abstract}

Passiflora incarnata, commonly known as purple passionflower or maypop, is an herbaceous perennial species native to North America which is grown as an ornamental in warm temperate climates for its unique floral traits, including multiple series of brightly colored coronal filaments and elaborate floral nectary structures (Torsten and MacDougal, 2004; Vanderplank, 1991). The flowers are usually solitary, up to $7.5 \mathrm{~cm}$ diameter, and highly decorative with pale lavender sepals and white to pale lavender linear petals in several series. The five stamens, usually pink to purple are borne on a gynophore with three styles projecting above the perianth (Griffiths, 1994). Supplied with a trellis or similar support, the vines make desirable landscape plants that provide nectar for butterflies, bees, and hummingbirds

Received for publication 26 Oct. 2016. Accepted for publication 21 Dec. 2016. This project was funded in part by the Texas A\&M AgriLife. Mention of a trademark, proprietary product, or vendor does not constitute a guarantee or warranty of the product by the authors, the Texas A\&M University, the Texas A\&M AgriLife, or sponsors of the research and does not imply its approval to the exclusion of other products or vendors that also may be suitable. The cost of publishing this paper was defrayed in part by the payment of page charges. Under postal regulations, this paper therefore must be hereby marked advertisement solely to indicate this fact.

${ }^{1}$ Corresponding author. E-mail: 1-lombardini@tamu.edu.
(Carr and Bagby, 1987; Knight et al., 1995). Although the flowers are usually open only $1 \mathrm{~d}$, the vines with flowers and ensuing calyces are used in floral arrangements for the floral industry. The fruits contain many seeds, each surrounded by an aril holding edible juice, which can be consumed fresh or used in processed products (McGuire, 1999). In addition, extracts of leaves, flowers, and roots of $P$. incarnata have been used as a medicinal plant since the 16th century because they have sedative, anxiolytic, and anticonvulsant effects on the central nervous system (Dhawan et al., 2001; Jawna-Zboińska et al., 2016). Passiflora incarnata has also been used in the treatment of addiction to alcohol, nicotine, and tetrahydrocannabinol, as well as, for diseases such as anxiety, insomnia, and convulsion (Jawna-Zboińska et al., 2016, Patel et al., 2009).

Global warming has altered precipitation patterns, increasing the frequency of drought in agricultural zones during the past few decades (Dai, 2011). Because plant growth and development can be strongly negatively affected by increased drought frequency (Lobell and Gourdji, 2012), characterization of the effects of water deficit on higher plants is important to estimate future suitability of changing environments for growing a particular plant species (Farooq et al., 2009). 
Plant response to drought is related to the intensity and duration of the stress and the growth stage of the plant during which the stress occurs (Obidiegwu et al., 2015; Xu et al., 2010). Different physiological processes such as growth, water relations, leaf gas exchange, and rubisco carboxylation efficiency are altered by water deficit (Farooq et al., 2009). Although the effects and physiological responses to drought have been widely studied in many plant crops, the literature available for $P$. incarnata is mainly focused on the effect of irrigation on growth and development of the root system (Bilalis et al., 2014) or the use of this species as rootstock for other Passiflora species under water stress conditions (Gesimba, 2008). However, little is known about the effects of drought on water potential and leaf gas exchange characteristics in shoots of $P$. incarnata. In general, the tolerance of Passiflora species to drought is low due to their shallow and fibrous root system (Fischer et al., 2009). However, Fernandez et al. (2014) stated that photosynthetic efficiency, chlorophyll fluorescence (Fv:Fm ratio), and predawn leaf water potential did not indicate the presence of stress in field-grown Passiflora ligularis during standard growing conditions.

Water stress affects plant growth because cell growth is one of the most drought-sensitive physiological processes due to the reduction in turgor pressure (Cosgrove, 2000). Carr (2013) stated that leaf production virtually ceased at leaf water potentials more negative than -2.0 MPa in passionfruit (Passiflora edulis). Likewise, a moderate water stress (soil water potential $=-0.075 \mathrm{MPa}$ ) diminished leaf area, but increased specific leaf weight (mass per area) in P. ligularis (CasierraPosada and Roa, 2006), suggesting that leaves became denser, likely due to a reduction in cell expansion. In addition, Menzel et al. (1986) concluded that moisture stress may be one of the major environmental factors responsible for yield fluctuations, because even mild soil moisture stress conditions (soil water potentials $=-0.01 \mathrm{MPa}$ ) reduced vine extension, and number of flower buds and open flowers.

Passiflora incarnata is a species that has potential for both its ornamental value and as a food source. However, little is known about morphological and biochemical adaptation of $P$. incarnata to drought stress conditions. The objective of this study was to determine the effects of drought stress on leaf water potential, and gas exchange in $P$. incarnata. The hypothesis was that $P$. incarnata has moderate-to-high resistance to drought conditions which would allow expanding its cultivation and its commercial value for the horticulture industry.

\section{Materials and Methods}

Plant material and growth Conditions. An experiment was conducted between Oct. and Dec. 2010 in the greenhouses of Texas A\&M University, in College Station (lat. 30 36' 30.34" N, long. $96^{\circ} 21^{\prime} 2.55^{\prime \prime} \mathrm{W}$, elevation $96 \mathrm{~m}$ ). The average greenhouse conditions during this period were the following: temperature of $21.3 \pm 0.3{ }^{\circ} \mathrm{C}$ day/17.4 $\pm 0.4{ }^{\circ} \mathrm{C}$ night, average photosynthetic photon flux density $(P P F D)$ of $395.3 \mu \mathrm{mol} \cdot \mathrm{m}^{-2} \cdot \mathrm{s}^{-1}$, and $51.5 \% \pm 2.9 \%$ relative humidity. At the beginning of October, 8-month-old, container-grown $P$. incarnata plants were purchased from a local wholesale nursery. Plants were planted in pairs in 4-L plastic pots, containing a mixture of 3:2 pine bark: native mulch/tree double grind (by volume) as substrate. Then, pots were fertilized with each irrigation using water-soluble, $20 \mathrm{~N}-4.4 \mathrm{P}-16 \mathrm{~K}$ fertilizer containing micronutrients (Peat-Lite
Special; Everris, Dublin, $\mathrm{OH}$ ) at a dose of $2 \mathrm{~g} \cdot \mathrm{L}^{-1}$. Plants were also sprayed with a rotation of etoxazole (TetraSan ${ }^{\circledR}$; Valent BioSciences Corp., Walnut Creek, CA), abamectin (Avid ${ }^{\circledR} 0.15$ EC; Syngenta, Greensboro, NC), and bifenazate (Floramite ${ }^{\circledR}$ SC; Chemtura Corp., Philadelphia, PA) at a dose of $0.025 \mathrm{~g} \cdot \mathrm{L}^{-1}$ a.i., $0.085 \mathrm{~g} \cdot \mathrm{L}^{-1}$ a.i., and $0.07 \mathrm{~g} \cdot \mathrm{L}^{-1}$ a.i., respectively, to control mites.

TreatMent APPLICATION AND EXPERIMENTAL DESIGN. Twenty pots, each containing two plants, were selected and arranged in a complete randomized design, with 10 pots assigned to each of two watering treatments: irrigation at container capacity (CT) and RI. Before the start of treatments, plants were watered and pots were weighed after drainage. After $24 \mathrm{~h}$, pots were weighed again and the amount of the daily consumption of water was calculated to determine the amount of water lost by ET $(100 \%$ ET). Daily ET ranged between 600 and $917 \mathrm{~mL} \cdot \mathrm{d}^{-1}$ of water per pot. Pots assigned to the CT treatment were irrigated with 100\% of their daily requirements for total ET throughout the entire experiment. The RI treatment was implemented stepwise to achieve a gradual water stress. For the first 8 DAT start, pots assigned to the RI treatment were watered with $50 \%$ of daily ET. From 9 to 16 DAT, the irrigation volume for the RI pots was lowered to $25 \% \mathrm{ET}$ and, between 17 and $30 \mathrm{DAT}$, to $10 \% \mathrm{ET}$. In the recovery phase (from 31 to 43 DAT) both RI and CT treatments were irrigated with the same amount of water $(100 \%$ ET). The soil volumetric water content (VWC) of each pot was measured daily during the experiment using a buriable time domain reflectometry probe (Trase model 6051V100; Soil Moisture Equipment, Santa Barbara, CA) that was left in place.

LeAF WATER POTENTIAL. Predawn leaf water potential $\left(\psi_{\mathrm{pd}}\right)$ was measured weekly using a Scholander type pressure chamber (model 3005; Soil Moisture Equipment) on one fully expanded leaf per pot. $\psi_{\text {pd }}$ measurements were carried out $1,8,15,22,29,36$, and 43 DAT.

Gas EXChange. Leaf gas exchange measurements were taken three times per week using a portable infrared gas analyzer (LI6400XT; LI-COR, Lincoln, NE). Measurements were taken on one fully expanded leaf selected in the top fourth portion of one vine per pot. A red:blue light source (model 6400-02B LED; LICOR) supplied $1200 \mu \mathrm{mol} \cdot \mathrm{m}^{-2} \cdot \mathrm{s}^{-1} P P F D$ which is light saturation as determined with a light response curve performed before the beginning of the experiment. Other settings included a reference level $\mathrm{CO}_{2}$ of $400 \mu \mathrm{mol} \cdot \mathrm{mol}^{-1}$, a constant chamber temperature of $25^{\circ} \mathrm{C}$, and a gas flow rate of $400 \mu \mathrm{mol} \cdot \mathrm{s}^{-1}$. Measurements were carried out between 1000 and 1430 HR. In addition, carboxylation efficiency and intrinsic water use efficiency $\left(\mathrm{WUE}_{\mathrm{i}}\right)$ were calculated by the following equations:

$$
\begin{gathered}
\text { Intrinsic water use efficiency }=\frac{\mathrm{P}_{\mathrm{n}}}{g_{\mathrm{s}}} \\
\text { Carboxilation efficiency }=\frac{\mathrm{P}_{\mathrm{n}}}{C_{\mathrm{i}}}
\end{gathered}
$$

where $\mathrm{P}_{\mathrm{n}}, g_{\mathrm{s}}$, and $C_{\mathrm{i}}$ are the photosynthetic rate, stomatal conductance, and substomatal $\mathrm{CO}_{2}$ concentration, respectively.

$\boldsymbol{A}: \boldsymbol{C}_{\mathrm{I}}$ AND LIGHT ReSponse CURVES. $A: C_{\mathrm{i}}$ curves (net $\mathrm{CO}_{2}$ assimilation rate, $A$, vs. calculated substomatal $\mathrm{CO}_{2}$ concentration, $C_{\mathrm{i}}$ ) and light response curves (net $\mathrm{CO}_{2}$ assimilation rate, $A$, vs. $P P F D)$ were performed at $8,16,30$, and 43 DAT on one leaf per pot. In $A: C_{\mathrm{i}}$ curves, chamber temperature was set at $25^{\circ} \mathrm{C}$ and $1200 \mu \mathrm{mol} \cdot \mathrm{m}^{-2} \cdot \mathrm{s}^{-1}$ irradiance, and $A$ was measured at nine $\mathrm{CO}_{2}$ levels in the following sequence: 400, 300, 200, 100, 50, 200, $400,600,800,1000$, and $1200 \mu \mathrm{mol} \cdot \mathrm{mol}^{-1}$. Measurements were 
carried out between 0900 and 1300 HR. Maximum carboxylation rate allowed by rubisco $\left(\mathrm{Vc}_{\max }\right)$, rate of photosynthetic electron transport [ $J$ (based on NADPH requirement)], TPU, light respiration $\left(R_{1}\right)$, and mesophyll conductance $\left(g_{\mathrm{m}}\right)$ were obtained by fitting data to the model described by Sharkey et al. (2007). In light response curves, $A$ was measured at nine $P P F D$ levels ( 0 , $20,50,100,200,500,800,1000$, and $\left.1500 \mu \mathrm{mol} \cdot \mathrm{m}^{-2} \cdot \mathrm{s}^{-1}\right)$ at $25{ }^{\circ} \mathrm{C}$ and a reference $\mathrm{CO}_{2}$ level of $400 \mu \mathrm{mol} \cdot \mathrm{mol}^{-1}$. Measurements were carried out between 0900 and 1200 HR. Maximum assimilation rate $\left(\mathrm{A}_{\max }\right)$, dark respiration $\left(R_{\mathrm{d}}\right)$, and light compensation point $\left(\mathrm{L}_{\mathrm{CP}}\right)$ were calculated by fitting data to the nonlinear regression model described by Hanson et al. (1987), with $P P F D$ levels as the independent variable.

SHOot LENGTH AND Relative GROWTH RATE. Six shoots per treatment were tagged when irrigation treatments started. Then, shoot length was recorded at 7, 14, 21, 28, and 35 DAT. Relative shoot length growth rate (RGR) was estimated at the end of each water stress phase with the following equation:

$$
\frac{\mathrm{RGR}=[\ln (\text { length at time } 2)-\ln (\text { length at time } 1)]}{(\text { time } 2-\text { time } 1)}
$$

Statistical anAlysis. Means and SE obtained for each data. Also, analysis of variance was performed to compare the effect of the different treatments. Where a significant $F$ test was observed, mean separation among treatments was obtained by Tukey's test. Data were analyzed using JMP statistical software (version 7.0; SAS Institute, Cary, NC). Graphs were performed using Sigmaplot software (version 10.0; Systat Software, San Jose, CA).

\section{Results and Discussion}

Soil VWC values in CT pots were between $25 \%$ and $32 \%$. In the RI treatment, there was a gradual decrease in VWC to a minimum VWC of $4.5 \%$ at 30 DAT (Fig. 1). After 30 DAT, in the recovery phase, VWC increased in the RI pots as these plants were irrigated with the same amount of water as the control pots. When the experiment ended (at 43 DAT) both treatments had the same VWC. At 30 DAT, CT plants had a greater shoot length than RI plants (Fig. 2A).

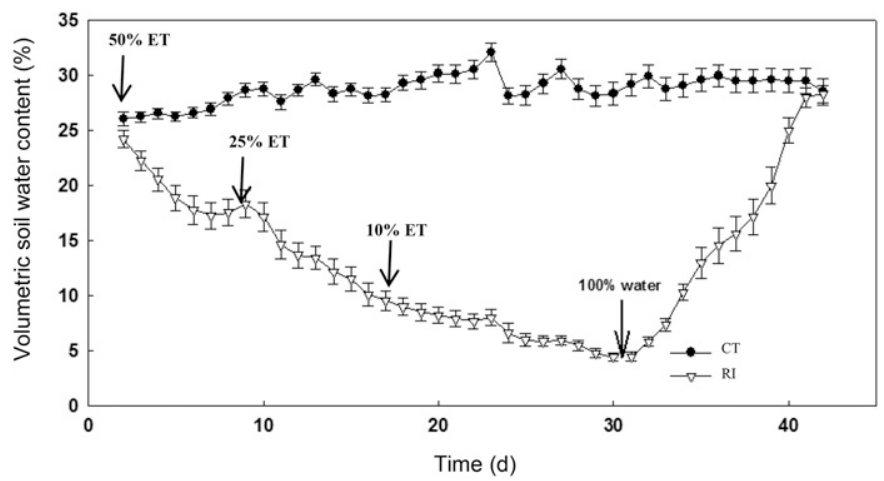

Fig. 1. Volumetric soil water content in pots of Passiflora incarnata subjected to two irrigation treatments, well-watered [irrigation at container capacity $(\mathrm{CT})$ ] and reduced irrigation (RI). CT plants were irrigated daily to replenish $100 \%$ evapotranspiration (ET), based on estimated daily water loss at the start of the experiment. RI treatment consisted of four sequential phases: $50 \%, 25 \%$, $10 \%$, and then $100 \%$ ET (recovery) and drought stress pots through time. Arrows indicate the beginning of each phase in the RI treatment. Data points indicate means \pm SE $(\mathrm{n}=10)$.
Shoot length was maintained greater even at the end of the recovery period, at 43 DAT. Similar trends were observed on RGR. Differences between treatments were obtained at the end of the $25 \%$ ET phase (16 DAT), being the RGR higher in control plants. Then, RI plants continued showing a lower RGR during the $10 \%$ ET and recovery phases in spite of the fact that in the recovery phase plants had been watered with $100 \%$ ET for $12 \mathrm{~d}$ (between 31 and 43 DAT) (Fig. 2B). In this sense, it has been reported that the water deficit induced by irrigation with $50 \%$ ET also caused a reduction on the shoot length in olive [Olea europaea (Arquero et al., 2006)], tamarillo [Cyphomandra betacea (Clavijo-Sanchez et al., 2015)], and passionfruit (Staveley and Wolstenholme, 1990).

It is well known that water stress affects plant growth because turgor pressure is reduced at cellular level (Cosgrove, 1993, 2000). In addition, shoot length is very sensitive to water shortage because drought periods reduce functionality of the root system, causing a lower uptake and movement of water and nutrients to the plant canopy, as well as lower photosynthetic rates due to stomatal closure (Roussos et al., 2010). Consequently,

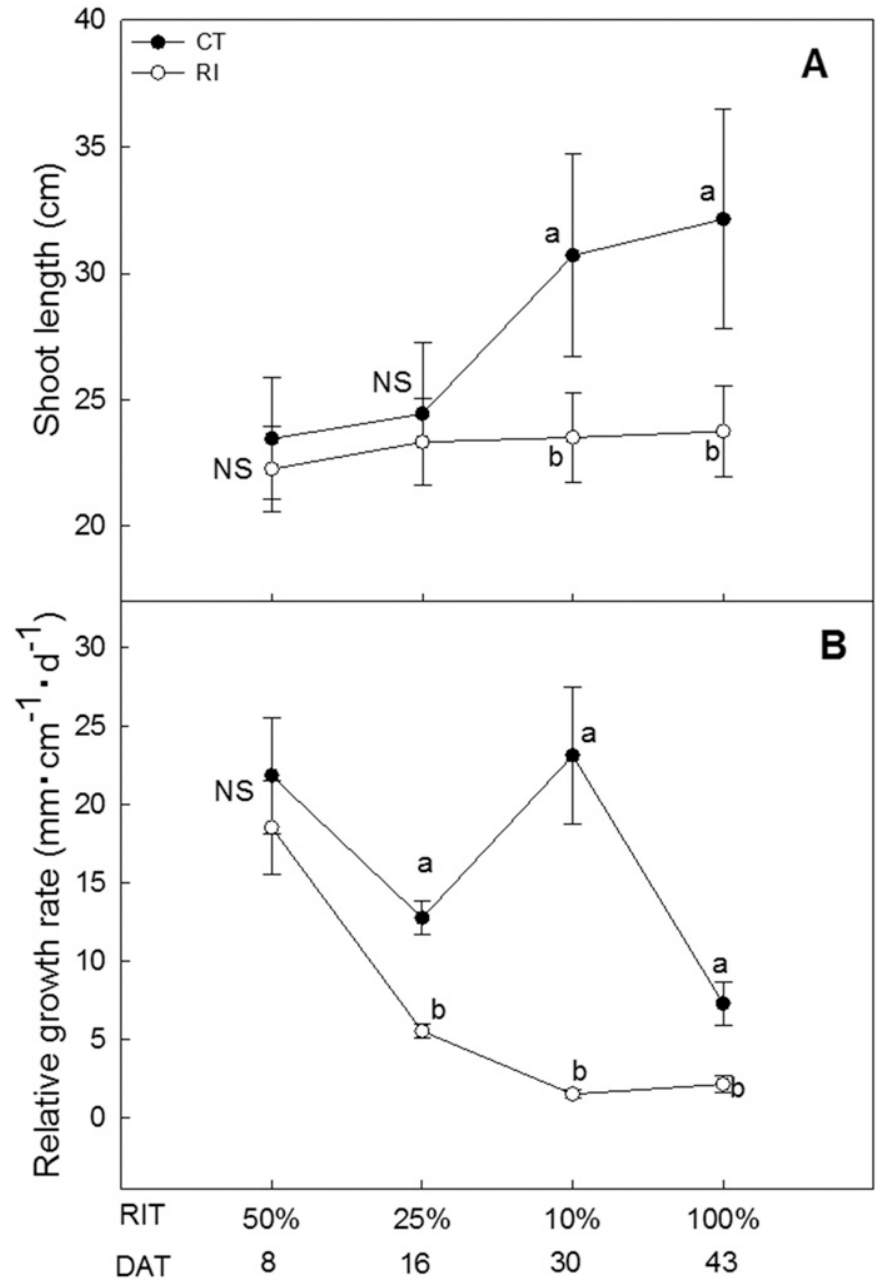

Fig. 2. (A) Shoot length and (B) relative growth rate of Passiflora incarnata plants subjected to two irrigation treatments, well-watered [irrigation at container capacity $(\mathrm{CT})$ ] and reduced irrigation (RI). CT plants were irrigated daily to replenish $100 \%$ evapotranspiration (ET), based on estimated daily water loss at the start of the experiment. RI treatment (RIT) consisted of four sequential phases: $50 \%, 25 \%, 10 \%$, and then $100 \%$ ET (recovery). The data points represent the means $\pm \mathrm{SE}(\mathrm{n}=10)$; DAT $=$ days after treatment start. 
drought slows the shoot growth more than root growth, causing the shoot:root ratio to decrease.

Leaf net photosynthesis rates were lower in RI plants than in CT plants from 10 to 30 DAT (Fig. 3). At 30 DAT, RI plants showed a photosynthesis rate of $2.5 \mu \mathrm{mol} \cdot \mathrm{m}^{-2} \cdot \mathrm{s}^{-1}$ compared with $8.5 \mu \mathrm{mol} \cdot \mathrm{m}^{-2} \cdot \mathrm{s}^{-1}$ in CT plant. In the recovery phase, leaf photosynthesis rate increased steadily in the RI treatment until the end of the experiment. At the last measurement day (43 DAT), gas exchange values were significantly higher for the recovered RI plants than for CT plants, $7.71 \mathrm{vs.} 4.75 \mu \mathrm{mol} \cdot \mathrm{m}^{-2} \cdot \mathrm{s}^{-1}$, respectively. Turner et al. (1996) also observed that waterstressed plants had reduced rates of photosynthesis compared with well-watered plants in passionfruit plants. They also observed that net photosynthesis increased rapidly during the recovery period, and there were no differences between drought-stressed plants and well-watered plants at the end of the experiment. It is widely documented that abiotic stresses, such as water deficit, can lead to inhibition of leaf photosynthesis due to damage of the photosynthetic apparatus, reduced stomatal aperture, light absorption, and alterations of the biochemical pathways of $\mathrm{CO}_{2}$ fixation (Farooq et al., 2009).

$A: C_{\mathrm{i}}$ curves can provide information on a number of important parameters to help understand leaf physiology under abiotic stress conditions (Darbah et al., 2010; Sharkey et al., 2007). Analysis of the $A: C_{\mathrm{i}}$ curves revealed that differences were only found on $\mathrm{Vc}_{\max }$ at $30 \mathrm{DAT}$ (10\% ET) (Fig. 4). $J$ and TPU were significantly higher in CT than in RI plants at 16 and 30 DAT, respectively, whereas $g_{\mathrm{m}}$ was higher for drought-stressed plants at $10 \%$ ET. Differences were not found on $R_{1}$ values between treatments through the experiment (data not shown). Studies carried out by Kwak et al. (2011) also found that $V_{\text {cmax }}$ and $J$ were lower in water-stressed plants of cork oak (Quercus suber).

In our experiment, carboxylation efficiency was reduced by $\approx 50 \%$ in RI plants after they were watered for $14 \mathrm{~d}$ with $10 \%$ ET (30 DAT) (Table 1), suggesting a limitation of the carboxylation activity of rubisco (Silva et al., 2013). On the

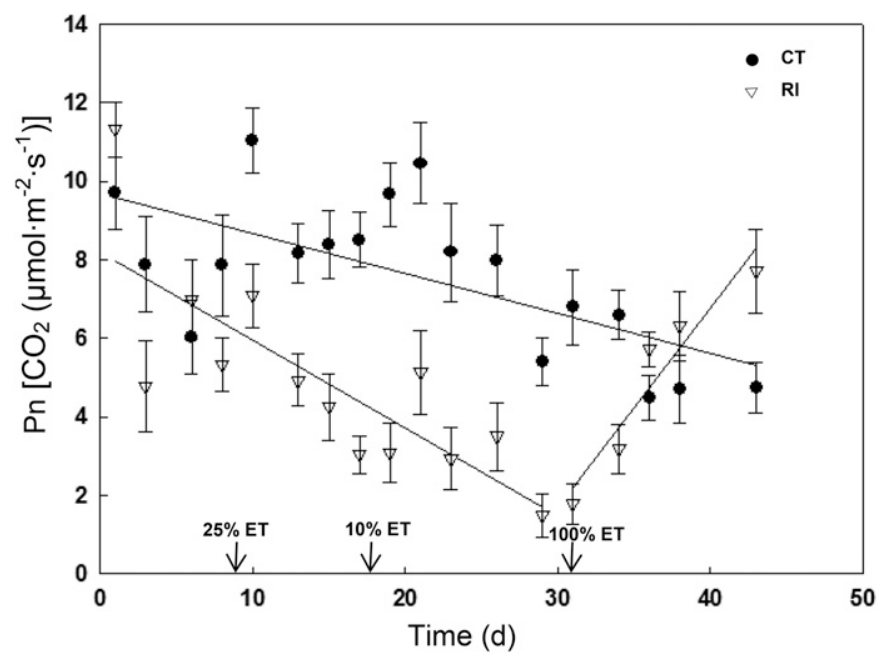

Fig. 3. Net carbon assimilation rate [photosynthetic rate $\left(\mathrm{P}_{\mathrm{n}}\right)$ ] of Passiflora incarnata plants subjected to two irrigation treatments, well-watered [irrigation at container capacity $(\mathrm{CT})]$ and reduced irrigation (RI). CT plants were irrigated daily to replenish $100 \%$ evapotranspiration (ET), based on estimated daily water loss at the start of the experiment. RI treatment consisted of four sequential phases: $50 \%, 25 \%, 10 \%$, and then $100 \% \mathrm{ET}$ (recovery), for $8,8,14$, and $13 \mathrm{~d}$, respectively. Arrows indicate the beginning of each phase in the RI treatment. Data are average $\pm \operatorname{SE}(n=10)$.

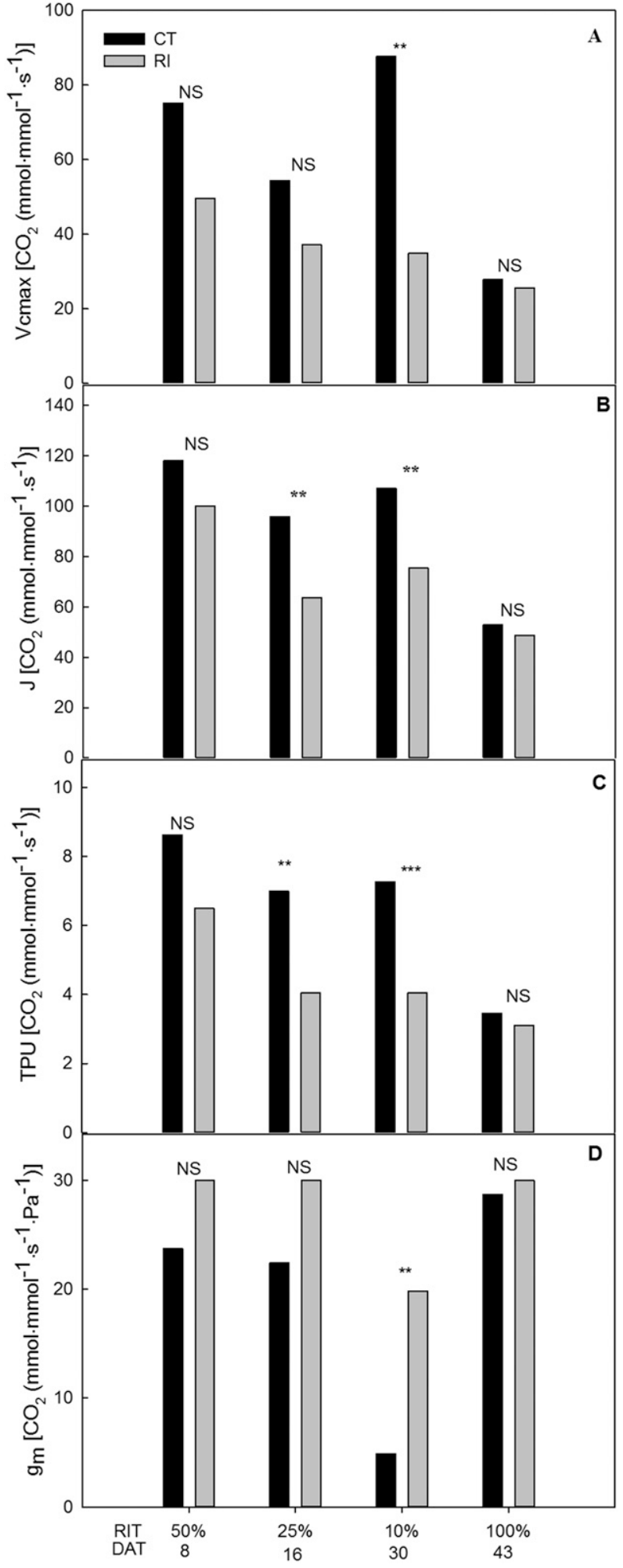

Fig. 4. Maximum carboxylation rate allowed by ribulose-1,5-biphosphate carboxylase/oxygenase $\left[(\mathbf{A}) \mathrm{Vc}_{\mathrm{max}}\right]$, rate of photosynthetic electron transport $\left[(\mathbf{B}) \mathrm{J}\right.$, triose phosphate use [(C)TPU], and mesophyll conductance $\left[(\mathbf{D}) g_{\mathrm{m}}\right]$ of potted Passiflora incarnata subjected to two irrigation treatments, wellwatered [irrigation at container capacity (CT)] and reduced irrigation (RI). CT plants were irrigated daily to replenish $100 \%$ evapotranspiration (ET), based on estimated daily water loss at the start of the experiment. RI treatment (RIT) consisted of four sequential phases: $50 \%, 25 \%, 10 \%$, and then $100 \%$ ET (recovery), for 8,14 , and $13 \mathrm{~d}$, respectively. Arrows indicate the beginning of each phase in the RI treatment. Data are average \pm SE $(n=10)$. 
Table 1. Carboxylation efficiency $\left(\mathrm{P}_{\mathrm{n}} / C_{\mathrm{i}}\right)$ and intrinsic water use efficiency (WUE $\left.\mathrm{E}_{\mathrm{i}}\right)$ in leaves of potted Passiflora incarnata subjected to two irrigation treatments, well-watered [irrigation at container capacity $(\mathrm{CT})$ ] and reduced irrigation (RI). CT plants were irrigated daily to replenish $100 \%$ evapotranspiration (ET), based on estimated daily water loss at the start of the experiment. RI treatment consisted of four sequential phases: $50 \%, 25 \%, 10 \%$, and then $100 \%$ ET (recovery). Data were calculated from gas exchange parameters measured at the end of each phase. The data represent the average of 10 plants per treatment.

\begin{tabular}{|c|c|c|c|c|c|c|c|c|}
\hline \multirow[b]{2}{*}{$\overline{\text { DAT }}^{z}$} & \multicolumn{4}{|c|}{$\mathrm{P}_{\mathrm{n}} / C_{\mathrm{i}}\left(\mathrm{mol} \cdot \mathrm{m}^{-2} \cdot \mathrm{s}^{-1}\right)$} & \multicolumn{4}{|c|}{$\mathrm{WUE}_{\mathrm{i}}\left(\mu \mathrm{mol} \cdot \mathrm{mmol}^{-1}\right)$} \\
\hline & 8 & 16 & 30 & 43 & 8 & 16 & 30 & 43 \\
\hline $\mathrm{RIT}^{\mathrm{z}}(\%)$ & 50 & 25 & 10 & 100 & 50 & 25 & 10 & 100 \\
\hline CT & 0.030 & 0.031 & 0.035 & 0.025 & 80.61 & 94.49 & 70.94 & 89.72 \\
\hline Significance & NS & NS & $*$ & NS & NS & NS & $* *$ & NS \\
\hline
\end{tabular}

${ }^{\mathrm{z}} \mathrm{DAT}=$ days after treatment start; RIT $=$ reduced irrigation treatment; $\mathrm{P}_{\mathrm{n}}=$ photosynthetic rate; $C_{\mathrm{i}}=$ substomatal $\mathrm{CO}_{2}$ concentration;

Ns, *, ** Nonsignificant or significant at $P=0.05$ or 0.01 , respectively.

other hand, RI plants at the end of extreme period $(10 \% \mathrm{ET})$ showed a greater $\mathrm{WUE}_{\mathrm{i}}$ than $\mathrm{CT}$ plants. Similar results were obtained in water-stressed passionfruit plants (De Sousa et al., 2005), four ornamental herbaceous perennials (Starman and Lombardini, 2006), and Populus genotypes (Monclus et al., 2006).

The determination of $\psi_{\mathrm{pd}}$ is useful for describing water stress effects (Farooq et al., 2009). In this experiment, low values of VWC $(<20 \%)$ induced more negative $\psi_{\text {pd }}(<-1.5$ $\mathrm{MPa}$ (Fig. 5). Likewise, an exponential decline of photosynthesis rate was observed when plants of $P$. incarnata showed a $\psi_{\mathrm{pd}}<-1.0 \mathrm{MPa}$ (Fig. 6), indicating that leaf water potential provides an integrated measurement of soil water status as it is sensed by the plants (Lima et al., 2002). Studies performed by Turner et al. (1996) showed that a leaf water potential more negative than $-1.5 \mathrm{MPa}$ also caused a reduction around $50 \%$ on net photosynthesis rate in leaves of Passiflora species.

Photosynthetic light response curves did not reveal differences between treatments after RI were irrigated with $50 \%$ ET for $8 \mathrm{~d}$ (Fig. 7A). However, the curves showed clear differences between irrigation regimes after RI plants were irrigated with

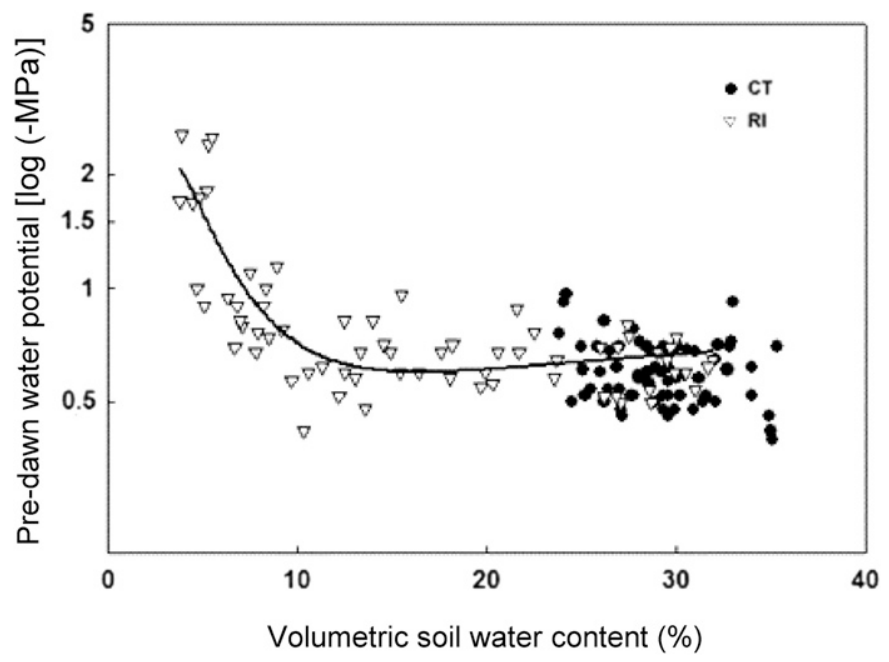

Fig. 5. Predawn water potential vs. volumetric soil water content of Passiflora incarnata plants subjected to two irrigation treatments, well-watered [irrigation at container capacity $(\mathrm{CT})]$ and reduced irrigation (RI). CT plants were irrigated daily to replenish $100 \%$ evapotranspiration (ET), based on estimated daily water loss at the start of the experiment. RI treatment consisted of four sequential phases: $50 \%, 25 \%, 10 \%$, and then $100 \% \mathrm{ET}$ (recovery), for $8,8,14$, and $13 \mathrm{~d}$, respectively. Data are average $\pm \mathrm{SE}(\mathrm{n}=10)$.
25\% ET and 10\% ET (Fig. 7B and C, respectively). After the recovery period, curves of $\mathrm{CT}$ and RI plants had similar $\mathrm{A}_{\max }$ (Fig. 7D). Reduced quantum use efficiency (assimilated $\mathrm{CO}_{2} /$ quanta received, QE) in leaves of RI plants irrigated with $25 \%$ ET and $10 \%$ ET (data not shown). QE values at the light saturation point decreased from 0.016 in CT plants, to 0.012 in $25 \%$ ET RI plants (data not shown). Likewise, RI plants watered with $10 \%$ ET had a lower QE in comparison with CT plants $(0.08$ vs. 0.01$)$.

Values of $A_{\max }$ were greater in well-watered pots than in drought stress pots (Table 2). After $8 \mathrm{~d}$ of irrigation with $50 \%$ ET and $8 \mathrm{~d}$ with $25 \%$ ET, $A_{\max }$ of RI plants was 3.74 $\mu \mathrm{mol} \cdot \mathrm{m}^{-2} \cdot \mathrm{s}^{-1}$, compared with $7.67 \mu \mathrm{mol} \cdot \mathrm{m}^{-2} \cdot \mathrm{s}^{-1}$ in CT plants (Table 2). After an additional $14 \mathrm{~d}$ of receiving $10 \% \mathrm{ET}, \mathrm{A}_{\max }$ of RI plans dropped to $1.39 \mu \mathrm{mol} \cdot \mathrm{m}^{-2} \cdot \mathrm{s}^{-1}$ compared with 5.89 $\mu \mathrm{mol} \cdot \mathrm{m}^{-2} \cdot \mathrm{s}^{-1}$ in CT plants.

Differences in $\mathrm{L}_{\mathrm{cp}}$ between the two treatments were only obtained during after recovery period when $\mathrm{CT}$ plants had a higher $\mathrm{L}_{\mathrm{cp}}$ than RI plants (Table 2). Xu et al. (2013) also found that moderate (60\% of field capacity) and high drought conditions $\left(40 \%\right.$ of field capacity) decreased $\mathrm{QE}, \mathrm{A}_{\max }$, and

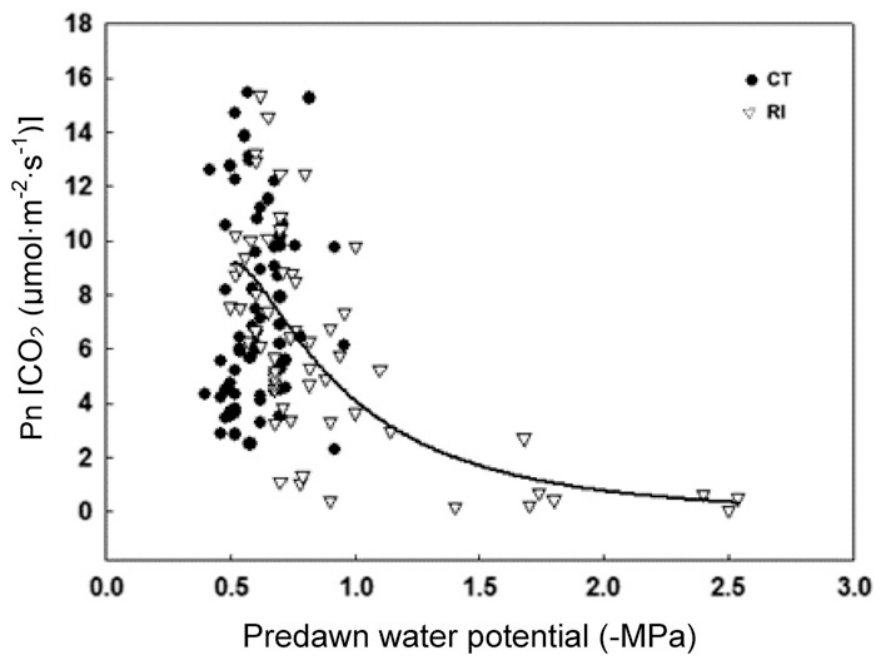

Fig. 6. Net carbon assimilation rate [photosynthetic rate $\left(\mathrm{P}_{\mathrm{n}}\right)$ ] vs. predawn water potential of Passiflora incarnata plants subjected to two irrigation treatments, well-watered [irrigation at container capacity $(\mathrm{CT})$ ] and reduced irrigation (RI). CT plants were irrigated daily to replenish $100 \%$ evapotranspiration (ET), based on estimated daily water loss at the start of the experiment. RI treatment consisted of four sequential phases: $50 \%, 25 \%, 10 \%$, and then $100 \%$ ET (recovery), for $8,8,14$, and $13 \mathrm{~d}$, respectively. Data are average $\pm \mathrm{SE}(\mathrm{n}=10)$. 


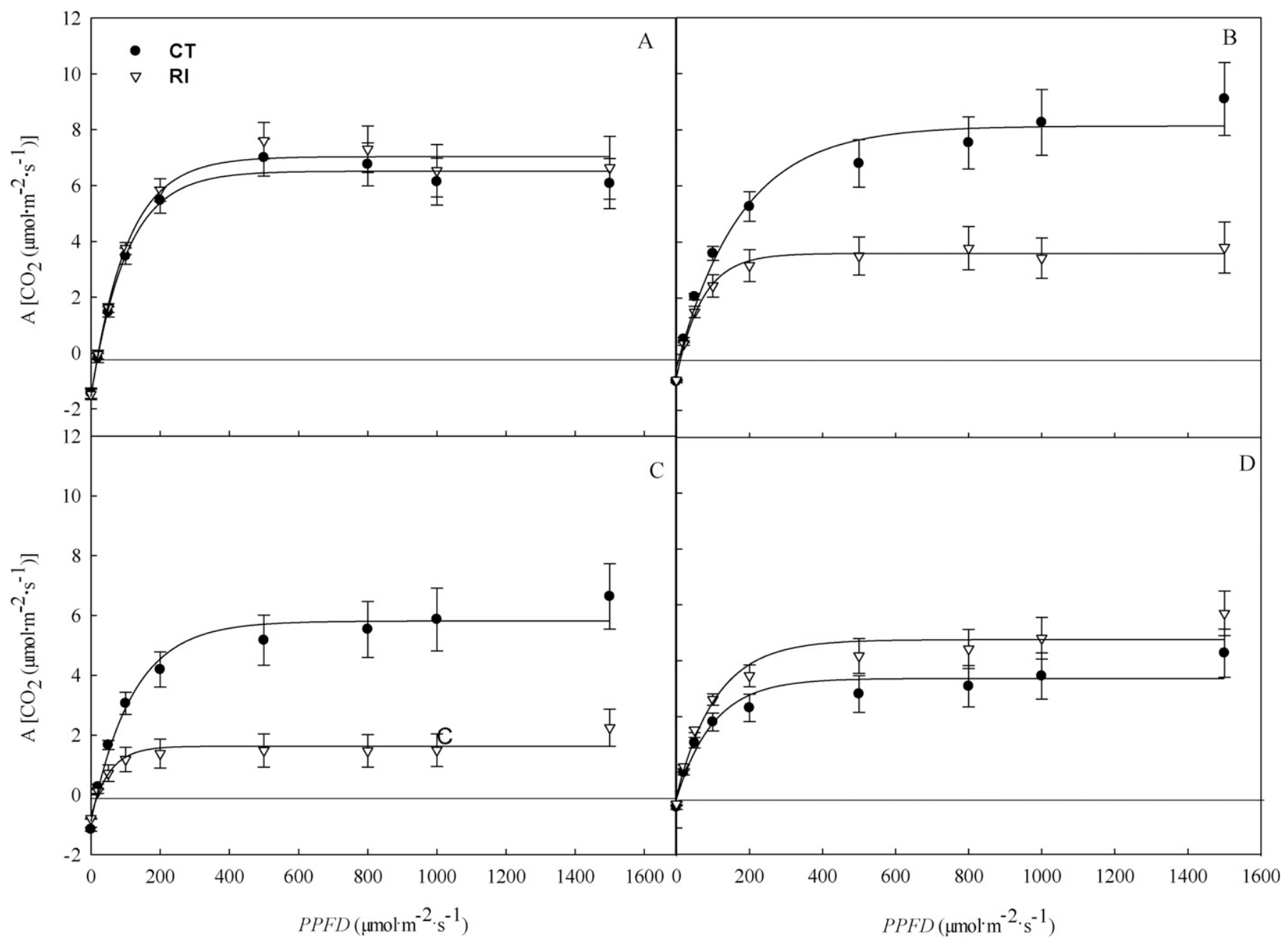

Fig. 7. Light response curves of Passiflora incarnata plants subjected to two irrigation treatments, well-watered [irrigation at container capacity (CT)] and reduced irrigation (RI). CT plants were irrigated daily to replenish $100 \%$ evapotranspiration (ET), based on estimated daily water loss at the start of the experiment. RI treatment consisted of four sequential phases: (A) $50 \%,(\mathbf{B}) 25 \%,(\mathbf{C}) 10 \%$, and then $100 \%$ ET [D (recovery)], for 8, 8, 14, and 13 d, respectively. Data are average \pm SE $(\mathrm{n}=10)$.

Table 2. Maximum photosynthetic rate $\left(\mathrm{A}_{\max }\right)$, and light compensation point $\left(\mathrm{L}_{\mathrm{CP}}\right)$ for leaves of Passiflora incarnata subjected to two irrigation treatments, well-watered [irrigation at container capacity (CT)] and reduced irrigation (RI). CT plants were irrigated daily to replenish $100 \%$ evapotranspiration (ET), based on estimated daily water loss at the start of the experiment. RI treatment consisted of four sequential phases: $50 \%, 25 \%, 10 \%$, and then $100 \%$ ET (recovery). Data were calculated from curves fitted for individual plants $(\mathrm{n}=10)$ with the method described by Hanson et al. (1987).

\begin{tabular}{|c|c|c|c|c|c|c|c|c|}
\hline \multirow[b]{2}{*}{$\mathrm{DAT}^{\mathrm{z}}$} & \multicolumn{4}{|c|}{$\mathrm{A}_{\max }\left[\mathrm{CO}_{2}\left(\mu \mathrm{mol} \cdot \mathrm{m}^{-2} \cdot \mathrm{s}^{-1}\right)\right]$} & \multicolumn{4}{|c|}{$\mathrm{L}_{\mathrm{cp}}\left[\mathrm{CO}_{2}\left(\mu \mathrm{mol} \cdot \mathrm{m}^{-2} \cdot \mathrm{s}^{-1}\right)\right]$} \\
\hline & 8 & 16 & 30 & 43 & 8 & 16 & 30 & 43 \\
\hline $\mathrm{RIT}^{\mathrm{z}}(\%)$ & 50 & 25 & 10 & 100 & 50 & 25 & 10 & 100 \\
\hline $\mathrm{CT}$ & 6.59 & 7.67 & 5.96 & 3.38 & 22.22 & 11.44 & 18.47 & 25.57 \\
\hline Significance & NS & $* *$ & $*$ & NS & NS & NS & NS & $*$ \\
\hline
\end{tabular}

${ }_{\mathrm{z}} \mathrm{DAT}=$ days after treatment start, RIT $=$ reduced irrigation treatment.

Ns, *, ** Nonsignificant or significant at $P=0.05$ or 0.01 , respectively.

$\mathrm{L}_{\mathrm{cp}}$ in yellow bluestem (Bothriochloa ischaemum) plants. In this sense, a decrease of QE under water stress conditions can be understood as a photoprotection mechanism, which is caused by the competition between thermal dissipation after receiving photosynthetic active radiations, and the photochemical reactions within the chloroplasts (Lawlor, 2002). Hence, this competition triggers a reduction in the light use efficiency and consequently lowering leaf photosynthesis rate (Chaves et al., 2003). In general, values of $R_{1}$ or $R_{\mathrm{d}}$ obtained respectively from either $A: C_{\mathrm{i}}$ or light-response curves did not show differences among water treatments (data not shown). Escalona et al. (1999) also observed that differences were negligible among irrigation treatments on $R_{\mathrm{d}}$ in grapevines. Thus, this lack of differences between treatments can be due the fact that water 
stress conditions did not affect severely the capacity of phosphorylation by $R_{\mathrm{d}}$ despite ATP synthesis could be impaired (Tezara et al., 1999).

In summary, stomatal mechanisms played an important role in the response of $P$. incarnata to water deficit. This study also revealed that nonstomatal factors such as rubisco activity, $J$ and TPU may be negatively affected by periods of intense drought. In addition, an exponential decline of photosynthesis rate was observed when plants of $P$. incarnata showed a $\psi_{\mathrm{pd}}$ more negative than $-1.0 \mathrm{MPa}$; however; leaf gas exchange properties showed a strong recovery when plants were watered at $100 \%$ ET after a period of RI.

Passiflora incarnata is sold as a landscape plant in most southern nurseries, where it is valued as a flowering vine, and it is well adapted to southern landscapes. Population growth and increased urbanization have increased competition for fresh water among agriculture, industry, and municipal water users (Lea-Cox and Ross, 2001). As water shortage and poor water quality challenge gardening and landscape practices in many regions of the world, the selection of drought-tolerant plants becomes increasingly important for the development of sustainable landscapes. Based on these results, $P$. incarnata can be considered moderately tolerant to short periods of water deficit and could adapt well to landscaping situations where periods of extreme drought can be expected.

\section{Literature Cited}

Arquero, O., D. Barranco, and M. Benlloch. 2006. Potassium starvation increases stomatal conductance in olive trees. HortScience 41: 433-436.

Bilalis, D., I. Kakabouki, F. Angelopoulou, P. Papastylianou, A. Karkanis, A. Konstantas, and I. Travlos. 2014. Effect of irrigation on growth and development of the root system of two medicinal plants, Hyssopus officinalis and Passiflora incarnata. Bul. Univ. Agr. Sci. 71:212-217.

Carr, M.K.V. 2013. The water relations and irrigation requirements of passion fruit (Passiflora edulis Sims): A review. Exp. Agr. 49:585596.

Carr, M.E. and M.O. Bagby. 1987. Tennessee plant species screened for renewable energy sources. Econ. Bot. 41:78-85.

Casierra-Posada, F. and H.A. Roa. 2006. Effect of moderate soil water deficit on growth and dry matter partitioning of granadilla plants (Passiflora ligularis Juss.). Revista U.D.C.A. Actualidad Divulgación Cientifica 9:169-180.

Chaves, M.M., J.P. Maroco, and J.S. Pereira. 2003. Understanding plant response to drought -from genes to the whole plant. Funct. Plant Biol. 30:239-264.

Clavijo-Sanchez, N., N. Florez-Velasco, and H. Restrepo-Diaz. 2015. Potassium nutritional status affects physiological response of tamarillo plants (Cyphomandra betacea Cav.) to drought stress. J. Agr. Sci. Technol. 17:1839-1849.

Cosgrove, D.J. 1993. Water-uptake by growing cells - an assessment of the controlling roles of wall relaxation, solute uptake, and hydraulic conductance. Intl. J. Plant Sci. 154:10-21.

Cosgrove, D.J. 2000. Loosening of plant cell walls by expansins. Nature 407:321-326.

Dai, A. 2011. Drought under global warming: A review. Wiley Interdiscip. Rev. Clim. Chang. 2:45-65.

Darbah, J.N.T., T.D. Sharkey, C. Calfapietra, and D.F. Karnosky. 2010. Differential response of aspen and birch trees to heat stress under elevated carbon dioxide. Environ. Pollut. 158:1008-1014.

De Sousa, V.F., J.A. Frizzone, M.V. Folegatti, and T.V.A. Viana. 2005. Water use efficiency of the yellow passion fruit under different irrigation levels and potassium doses. Rev. Bras. Eng. Agr. Ambient. 9:302-306.
Dhawan, K., K. Suresh, and A. Sharma. 2001. Anxiolytic activity of aerial and underground parts of Passiflora incarnata. Fitoterapia 72:922-926.

Escalona, J.M., J. Flexas, and H. Medarano. 1999. Stomatal and nonstomatal limitations of photosynthesis under water stress in fieldgrown grapevines. Austral. J. Plant Physiol. 26:421-433.

Farooq, M., A. Wahid, N. Kobayashi, D. Fujita, and S.M.A. Basra. 2009. Plant drought stress: Effects, mechanisms and management. Agron. Sustain. Dev. 29:185-212.

Fernandez, G.E., L.M. Melgarejo, and N.A. Rodríguez. 2014. Some aspects of the photosynthesis and water potentials in the reproductive phase of sweet granadilla (Passiflora ligularis Juss.) in Huila, Colombia. Revista Colombiana Ciencias Hortícolas 8:206-216.

Fischer, G., F. Casierra-Posada, and W. Piedrahita. 2009. Ecophysiology of Passifloraceae species cultivated in Colombia, p. 45-67. In: D. Miranda, G. Fischer, C. Carranza, S. Magnitskiy, F. CasierraPosada, W. Piedrahíta, and L.E. Flórez (eds.). Cultivo, poscosecha y comercialización de las pasifloráceas en Colombia: Maracuyá, granadilla, gulupa y curuba. Sociedad Colombiana de Ciencias Hortícolas, Bogotá, Colombia.

Gesimba, R.M. 2008. Screening Passiflora species for drought tolerance, compatibility with purple passion fruit, Fusarium wilt resistance and the relationship between irrigation, drenching and media composition in the control of Fusarium wilt. Ohio State Univ., Columbus, PhD Diss.

Griffiths, M. 1994. Index of garden plants. MacMillan, London, UK. Hanson, P.J., R.E. McRoberts, J.G. Isebrands, and R.K. Dixon. 1987. An optimal sampling strategy for determining $\mathrm{CO}_{2}$ exchange rate as a function of photosynthetic photon flux density. Photosynthetica 21:98-101.

Jawna-Zboińska, K., K. Blecharz-Klin, I. Joniec-Maciejak, A. Wawer, J. Pyrzanowska, A. Piechal, D. Mirowska-Guzel, and E. WidyTyszkiewicz. 2016. Passiflora incarnata L. improves spatial memory, reduces stress, and affects neurotransmission in rats. Phytother. Res. 30:781-789.

Knight, R.J., Jr., J.A. Payne, R.J. Schnell, and A.A. Amis. 1995. 'Byron Beauty', an ornamental passion vine for the temperate zone. HortScience 30:1112.

Kwak, M.J., S.H. Lee, and S.Y. Woo. 2011. Physiological and biochemical traits of different water and light intensities on cork oak (Quercus suber L.) seedlings. Afr. J. Biotechnol. 10:15305-15319.

Lawlor, D.W. 2002. Limitation to photosynthesis in water-stressed leaves: Stomata vs. metabloism and the role of ATP. Ann. Bot. (Lond.) 89:871-885.

Lea-Cox, J.D. and D.S. Ross. 2001. A review of the Federal Clean Water Act and the Maryland Water Quality Improvement Act: The rationale for developing a water and nutrient management planning process for container nursery and greenhouse operations. J. Environ. Hort. 19:226-229.

Lima, A.L., F.M. DaMatta, H.A. Pinheiro, M.R. Totola, and M.E. Loureiro. 2002. Photochemical responses and oxidative stress in two clones of Coffea canephora under water deficit conditions. Environ. Expt. Bot. 47:239-247.

Lobell, D.B. and S.M. Gourdji. 2012. The influence of climate change on global crop productivity. Plant Physiol. 160:1686-1697.

McGuire, C. 1999. Passiflora incarnata (Passifloraceae): A new fruit crop. Econ. Bot. 53:161-176.

Menzel, C.M., D.R. Simpson, and A.J. Dowling. 1986. Water relations in passionfruit: Effect of moisture stress on growth, flowering and nutrient uptake. Sci. Hort. 29:239-249.

Monclus, R., E. Dreyer, M. Villar, F.M. Delmotte, D. Delay, J.-M. Petit, C. Barbaroux, D. Le Thiec, C. Bréchet, and F. Brignolas. 2006. Impact of drought on productivity and water use efficiency in 29 genotypes of Populus deltoids $\times$ Populus nigra. New Phytol. 169:765-777.

Obidiegwu, J.E., G.J. Bryan, H.G. Jones, and A. Prashar. 2015. Coping with drought:stress and adaptive responses in potato and perspectives for improvement. Front. Plant Sci. 6:542-565. 
Patel, S.S., T.S.M. Saleem, V. Ravi, B. Shrestha, N.K. Verma, and K. Gauthaman. 2009. Passiflora incarnata Linn: A phytopharmacological review. Intl. J. Green Pharmacy 3:277-280.

Roussos, P.A., N.K. Denaxaa, T. Damvakarisa, V. Stournarasa, and I. Argyrokastritis. 2010. Effect of alleviating products with different mode of action on physiology and yield of olive under drought. Sci. Hort. 125:700-711.

Sharkey, T.D., C. Bernacchi, G.D. Farquhar, and E.L. Singsaas. 2007. Fitting photosynthetic carbon dioxide response curves for $\mathrm{C} 3$ leaves. Plant Cell Environ. 30:1035-1040.

Silva, M.A., J.L. Jifon, C. Moura dos Santos, C.J. Jadoski, and J.A. Gonçalves da Silva. 2013. Photosynthetic capacity and water use efficiency in sugarcane genotypes subject to water deficit during early growth phase. Braz. Arch. Biol. Technol. 56:735-748.

Starman, T. and L. Lombardini. 2006. Growth, gas exchange, and chlorophyll fluorescence of four ornamental herbaceous perennials during water deficit conditions. J. Amer. Soc. Hort. Sci. 131: 469-475.
Staveley, G.W. and B.N. Wolstenholme. 1990. Effects of water stress on growth and flowering of Passiflora edulis (Sims) grafted to $P$. caerulea L. Acta Hort. 275:551-558.

Tezara, W., W.J. Mitchell, S.D. Driscoll, and D.W. Lawlor. 1999. Water stress inhibits plant photosynthesis by decreasing coupling factor and ATP. Nature 401:914-917.

Torsten, U. and J.M. MacDougal. 2004. Passiflora: Passionflowers of the world. Timber Press, Portland, OR.

Turner, D.W., C.M. Menzel, and D.R. Simpson. 1996. Short-term drying of half the root system reduces growth but not water status or photosynthesis in leaves of passionfruit (Passiflora sp.). Sci. Hort. 65:25-36.

Vanderplank, J. 1991. Passion flowers and passion fruit. 1st ed. MIT Press, Cambridge, MA.

Xu, W.Z., X.P. Deng, and B.C. Xu. 2013. Effects of water stress and fertilization on leaf gas exchange and photosynthetic light-response curves of Bothriochloa ischaemum L. Photosynthetica 51:603-612. $\mathrm{Xu}$, Z.L., G. Zhou, and H. Shimizu. 2010. Plant responses to drought and rewatering. Plant Signal. Behav. 5:649-654. 